\begin{tabular}{c} 
International Journal of Basic and Applied Sciences, $7(2)(2018) 20-29$ \\
SPC \\
Website: $\begin{array}{c}\text { www.sciencepubco.com/index.php/IJBAS } \\
\text { doi: } 10.14419 / \text { ijbas.v7il.7536 } \\
\text { Research paper }\end{array}$ \\
\hline
\end{tabular}

\title{
An evaluation of the current status of EIA system in Pakistan focusing Khyber Pakhtunkhwa
}

\author{
Deedar Ahmed ${ }^{1 *}$, Abdullah Khan ${ }^{1}$, Zulfiqar Ali $^{2}$, Daulat Khan ${ }^{3}$,Ihsan Ullah Afridi ${ }^{4}$ \\ ${ }^{1}$ Department of Environmental Sciences, University of Haripur \\ ${ }^{2}$ Department of Urban \& Regional Planning, University of Peshawar \\ ${ }^{3}$ Department of Agricultural Engineering, UET Peshawar \\ ${ }^{4}$ Department of Environmental Sciences, University of Peshawar \\ *Corresponding author E-mail:deedarabir@gmail.com
}

\begin{abstract}
Pakistan, like many other developing countries has adopted the integration of environmental concerns in its social and economic planning. Pakistan has developed some environmental legislation and policies at the national level for the protection and conservation of environment. This paper evaluates the current status of the environmental assessment system in Pakistan and especially in the Khyber Pakhtunkhwa (KP) province by using the Christopher Wood Evaluation Model. The EIA system in Pakistan has many strong features like the legal basis for assessment process, strong apprehension and willingness for screening and scoping, stakeholder's involvement and participation, mitigation of impacts, and cost \& benefits of EIA system. The limitations found in the assessment process of Pakistan includes Preparation of EIA report and its review, monitoring and auditing, strategic environmental assessment, while consideration of alternatives and decision making mechanisms are completely ignored. Besides these, the study revealed the practice of ineffective remedial measures, non-professional, inexperience and unregistered consultants involved in the environmental assessment and sporadically the politically oriented decision making process. This evaluation led to a series of suggestions regarding the improvement of EIA system in Pakistan and especially KP Province with a view to develop its quality and effectiveness.
\end{abstract}

Keywords: Christopher Wood Model; Decision Making; EIA; EPA; KP.

\section{Introduction}

An EIA focuses on problems, social issues and natural resource restrictions which might affect the feasibility of a project. EIA also identifies how the project could do well or harm to the community, their homeland, their way of livings and the other developmental activities in proximity. Environmental Impact Assessment (EIA) involves the check, analysis and consideration of activities planned with a view to guarantee environmentally feasible and sustainable growth. Thus EIA can be considered as an efficient and useful planning and management tool [[1]].A series of models for the evaluation of effectiveness of EIA process have been developed in the past. The processes of EIA were evaluated in developing countries by Hirji \& Ortolano in 1991 by introducing their model [2]. The authors evaluated the effectiveness of EIA by using different criteria in water resource development in Kenya [[2]]. In 1996, an EIA oriented model was produced which based on categorical evaluation. This type of model has been applied in Taiwan [[3]]. Similarly, the Christopher Wood also presented a model of evaluation comprises fourteen criteria. Christopher model has been used effectively for both the developed and developing countries. The authors applied this model effectively for the evaluation of Hong Kong EIA procedures [[4]]. It was used for comparison of eight countries in Europe [[5]].The same model was applied for Egypt, Turkey and Tunisia [[6]]. Wood model was used for evaluation of EIA system in Pakistan [[7]].Due to public demand and rising pressure on the government to accept liability regarding the activities of its agencies, the National Environmental
Policy Act (NEPA) was promulgated in United States of America in 1969. This had provided the actual ground for the growth of a mechanism which appeared as EIA[[8]].The motivational factors resulted in development of procedures for EIA in 1970s due to the environmental losses caused by mega developmental projects like highways, dams, mining and electric power plants. The developed and developing nations adopted the EIA requirements. The US courts also became active in enforcement of the Environmental Impact Statements (EIS). The EIA requirements was gradually established and recognized by the developed nations via legislations [[1]].The growing international environmental concern and other factors with cumulative effect in Pakistan led to the wideranging law on environment, drafted in the mid-1970s. Although for years it was not considered as agenda item of the parliament. Lastly this draft received presidential assent and thus led to the enactment of 1983, Pakistan Environmental Protection Ordinance (PEPO). The promulgation of this ordinance was followed by the Pakistan Environmental Protection Act (PEPA) on $3^{\text {rd }}$ December 1997[[9]].Therefore, according to section 12 of the PEPA1997, no proponent shall commence a project construction or operation unless and until he undergoes for an Initial Environmental Examination or in case of negative impacts an EIA either with the Federal or Provincial agency and may seek for the legal approval[[10]]. In Pakistan, the EIA process also became mandatory due to the requirement of donor agencies like the World Bank, Asian Development Bank and growing pollution level due to industrial processes, vehicular emissions, deforestation and urban sprawl. Comparatively the process of EIA is a new subject to Pakistan and needs some time to be implemented for all those projects which 
are likely to cause the adverse impacts on environment. The donor agencies in Pakistan have developed their own EIA guidelines and are applicable for developmental activities. The core objectives of this research study were to evaluate the current status of EIA system in Pakistan and especially in KP province by using the Christopher Wood Model, find out the efficiencies and deficiencies in the system, identify the level of public participation and to develop an environmental monitoring plan for environmental compliance \& reporting and make valuable suggestions for further implementation.

\section{Methodology}

A simple set of methods have been used in this research study in order to examine the EIA process and legal obligations governing this system in Pakistan and especially in KP province.

Christopher Wood Model Based on fruitful results and effective applications of the Christopher Wood Model in a series of developing countries, this model was deemed effective for evaluation of the EIA system of Pakistan. Pakistan has a growing economy and exponential growth in population. Therefore, there is a growing pressure on the natural resources and an effective implementation of the EIA system is needed. In this way, this analysis will help in improving the EIA procedures if its implementations are ensured. The criteria used for selecting Christopher Wood Model are given below:

i) Is the EIA system based on clear and specific legal provisions?

ii) Must the relevant environmental impacts of all significant actions be assessed?

iii) Must evidence of the consideration, by the proponent, of the environmental impacts of reasonable alternative actions be demonstrated in the EIA process?

iv) Must screening of actions for environmental significance take place?

v) Must scoping of the environmental impacts of actions take place and specific guidelines be produced?

vi) Must EIA reports meet prescribed content requirements and do checks to prevent the release of inadequate EIA reports exist?

vii) Must EIA reports be publicly reviewed and the proponent responds to the points raised?

viii) Must the findings of the EIA report and the review be a central determinant of the decision on the action?

ix) Must monitoring of action impacts be undertaken and is it linked to the earlier stages of the EIA process?

$\mathrm{x})$ Must the mitigation of action impacts be considered at the various stages of the EIA process?

xi) Must consultation and participation take place prior to, and following EIA report publication?

xii) Must the EIA system be monitored and, if necessary, be amended to incorporate feedback from experience?

xiii) Are the financial costs and time requirements of the EIA system acceptable to those involved and are they believed to be outweighed by discernible environmental benefits?

xiv) Does the EIA system apply to significant programs, plans and policies, as well as to projects?

For an effective application of the criteria of the Christopher Wood evaluation model, a series of approaches like personal communication and group discussions with the senior officials of EPA KP province, online scholarly articles, existing literature on environmental laws and regulations and Pakistan environmental assessment procedures were reviewed. Besides, the IEE and EIA documents and remarks of the review committee along with the field visits to different proposed project sites like the composting plant at Ghari Baghbanan Peshawar, Plaster of Paris unit at Karak and Matiltan hydropower project Swat were deem necessary. These three case studies are mentioned as CS1, CS2 and CS3 respectively.

\section{Results}

The fourteen criteria of the Christopher Wood Model were used as assessment tool and the results are given as under.

\subsection{Legal grounds for EIA system}

The legal, political, administrative \& socioeconomic conditions of a country have significant influence on the EIA system. The process of EIA was legally adopted after the enactment of PEPA 1997. According to PEPA 1997, every proponent should submit an EIA or IEE as the case may be in response to the expected adverse environmental impacts. Under this Act the EIA study for composting plant at Peshawar (CS1), IEE study for Plaster of Paris unit (CS2) were recommended. While EIA study for Matiltan hydro power project at Swat (CS3) was conducted prior to enactment of PEPA 1997. Thus it is obvious that the present EIA system in Pakistan \& KP province meets the requirement of Christopher Wood first criterion.

\subsection{Scope of coverage of EIA process}

As per section 12 of PEPA 1997, the proponent is asked to do the assessment process when the developmental activity is likely to deteriorate the environment but in Pakistan as well as in the provincial EIA system there are some developmental activities where the assessment process is not mandatory e.g. the brick kiln, stone crushing units and poultry farms which pose serious threat to environment. These projects may follow some guidelines which exempt it from the process of assessments. In Pakistan the donor funded projects and those projects which fall under schedule I and II undergo the process of assessments.

The composting plant project at Peshawar was not fully executed while the Plaster of Paris unit at district Karak of KP adopted the assessment process. Matiltan Hydropower project was politically oriented and the environmental impacts were not completely assessed because this study was conducted before the promulgation of PEPA 1997 .Thus the EIA system partially meets this criterion of Christopher Wood Model.

\subsection{Consideration of alternatives in the EIA process}

A logical and well established series of efficient alternative options like demand tilting, activity based, location, processing or input alternatives exists in EIA system of Pakistan but these options are rarely exercised by the proponent because these are sometime research based and expensive. Similarly, political influence also plays an important hindrance in alternative site selection. Therefore, the proponents often skip this criterion and these options are not provided in the assessment document so far. Pakistan EIA system meets this criterion but in actual practice these alternative options are not exercised in any of the developmental activity in KP. The KP EIA process doesn't meet this criterion of Christopher Wood Model.

\subsection{Screening of activities}

In screening process the proposed project is judged that either it needs to submit an EIA or not. The overall impacts are taken into account in this process. Screening process is a technique through which the project is categorized on the basis of its impacts. According to section 13(1) of KPEPA 2014, no proponent shall commence construction or operation of any developmental project before the submission of an IEE report with the concerned agency or an EIA in case of negative environmental consequences expected from the activity. The Federal EPA has furnished a list of different projects that require either the submission of EIA or IEE. Thus screening is the backbone of EIA process and sponsored by the EPA. So the EIA system throughout Pakistan fulfills this criterion of Christopher Wood Model. 


\subsection{Scoping of impacts}

At this stage noteworthy issues and impacts are identified which needs further investigation and are evaluated during EIA process. As a result of the screening process if the IEE report is unsatisfactory and needs detailed investigation then an EIA is preferred. This is the first stage of EIA process which needs detail information and expert opinion regarding the evaluation of impacts and associated issues with proposed project. The issues of great concern are categorized in scoping to be assessed further. It is clear from the EIA system of Pakistan that scoping can be exercised for the environmental impacts identification and provision of logical alternatives, highlights the impacts of the activity and make it public, consider the limitations of actions, suggest remedial steps to potentially expected impacts and assist the establishment of the terms of reference which may facilitate the process of assessment Thus the EIA system of Pakistan and KP province meets the Christopher Wood's criterion in scoping procedure.

\subsection{EIA report preparation}

Environmental reporting plays a vital role in the process of EIA. This report is a source to convey the environmental impacts of the proposed projects. The report must address the significant consequences expected during the implementation of the project and should summarize the report so that understandable to common person. Unfortunately the EIA report in KP is often compiled by ordinary consultants who are inexperienced and least qualified in the area of environment. These consultants sometimes replicate the same report for other project of same nature and business. It is clear from the EIA system of Pakistan that there exist the practice of assessment document presentation but its quality is beyond description.

The assessment reports of case studies 1 and 2 were prepared as per the IEE/EIA guidelines but the case study No.3 assessment report prepared before the enactment of PEPA 1997 and presented in 2011. The Pakistan EIA system meets this criterion of Christopher Wood Model but in KP this criterion is partially meet by the present EIA practice.

\subsection{Review of EIA report}

The process of review is now an extra burden over the reviewers because they don't receive any incentives in monetary terms or any appreciation letter which encourage them and augment their interest in review process. Due to its unrewarding nature, this process is very weak and ineffective. A general review is carried out and the EIA secretary usually collect the comments from the review committee members where these comments are copied and pasted from one another and processed on relevant file for onward decision making. Besides, the review committee lacks the diverse skill and professional experience in all projects. Like for example in case of hydropower project the expert opinion of the hydrologist is important but the present reviewers composition in KP are mostly comprised chemists and botanists. Thus it is clear from above that Pakistan and KP province EIA system partially meets this criterion of the Christopher's Wood Model.

\subsection{Process of decision making}

The process of decision making play pivotal role in the whole EIA although this process was found unacceptable due to numerous limitations including political or administrative rising pressure, lack of expert opinion \& professional skills, lack of scientific based remedial steps, poor qualitative and quantitative assessments and underprivileged review process. For instance the CS1 project was politically approved and the environmental approval received just for fund raising from donor agency and after grant of environmental approval and financial sanction from World Bank the project was not implemented. Similarly CS3 project study was conducted and completed in 1996 and this project received the legal assent in November 21, 2011 subject to that study. The data generated as a result of the assessment process was too much classical and EIA study needs a fresh set of information. This project was dictatorially approved and the leading decision maker was the Provincial government, KP Province while only the CS2 project was implemented technically and consultatively. This criterion of Christopher Wood model doesn't meet by the present EIA system of Pakistan and KP Province

\subsection{Monitoring and auditing}

The process of monitoring and auditing is a mirage. This term only exist in the official documents and actually it is not in practice. This study reveals that the monitoring is done only on the directives of the apex court or in pursuance of a complaint received from community. The EPA, KP also lacks the constructed monitoring plan or Performa which can make effective monitoring and compliance. Usually the field visits are paid and the general observations are recorded. The field force is not always provided with the necessary analytical equipment's and transportation services. The CS1 project was not fully executed and CS2 project was once monitored in a monitoring campaign while the CS3 project was not monitored due to far flung area as well as law and order situation in Swat. This criterion of Christopher Wood model is not effectively fulfilled.

\subsection{Mitigation of impacts}

The term mitigation means, that techniques or approach used to minimize the negative consequences of any recommended project on the environment. The measures may be alteration in the process to decrease emissions, appropriate project modifications, installation of effective pollution control equipment in accordance with the modern technology and adjustment of the operation timings of the plant. In the EIA system of Pakistan the mitigation measure are proposed at construction phase, operational phase of the project as well as the conditional environmental approval is granted. Besides, the Environmental Management Plan (EMP) is given in the assessment report which is applicable for the proposed project. In this study the mitigation measure in CS1 project were effective and up to the standard while in the CS2 project the remedial step at operational phase were not fully adopted due to extra cost and the CS3 remedial steps were also not fully adopted due to political mounting pressure. It is concluded from the above discussion, that the Pakistan and KP Province, EIA system has procedure for remedial measures and meet the Christopher's Wood criterion.

\subsection{Consultation and participation}

Public participation is an integral part of EIA. According to section 10 of IEE/ EIA regulations 2000, any activity which poses threat to environment and general public, then a general body meeting to be arranged at the proposed site by the proponent. The participants include the public in proximity to the site, representatives from EPA, concerned government departments and civil society. The participation notice to general public is given through print media and target communities are informed by handing them over the letter for participation and as a result the interested parties make sure the participation and contribute to the process of EIA. This study reveals that the CS1 project effectively arranged the public gathering at the proposed site and the grievances of the public were recorded while the CS2 project was an IEE study and according to Regulations 2000, it's exempt from the public consultation. Similarly the public gathering of the CS3 project arranged in lower Swat Mingora, and the locals of the proposed site participated successfully. It is concluded from the above discussion that the Pakistan and KP, EIA system meets the Christopher wood's criterion.

\subsection{Monitoring of EIA system}


The effectiveness of the environmental reports as the project proceeds further can be best understand as a result of monitoring. The process of monitoring keeps alert the implementation of agreed remedial measures prior to the impacts when expected to attain the objectionable limit. The process of monitoring includes monitoring program, sample collection, analysis, interpretation of the recorded observations and submission of detailed visit report. The process of post monitoring is seldom carried out due to numerous constraints like the limited resources include equipments, field force, lack of EPA district \& divisional offices and transportation services.

For an effective environmental monitoring and compliance there is a need of constructed environmental monitoring plan where environmental boundaries should be specified and restriction is placed on the reporter for compliance accordingly. The EIA system of Pakistan has no provision to maintain the monitoring record for future reference or for utilizing this record as precedence for identical projects. Thus, this criterion of Wood's model is not effectively meet by the Pakistan and KP Province, EIA system.

\subsection{Cost and benefits of EIA system}

For a successful EIA process since scoping to decision making and monitoring needs the availability of reasonable monetary resources and time. The available funds for EIA are not defined but usually it range from 0.5 to $1.0 \%$ against the total cost of the proposed activity. This fund is allocated to various components like for instance preparation and review process and for the purpose of public participation etc. In some cases due to some reasonable circumstances the public participation gets delay which deems necessary the further consultation or another alternate option in the study and this contribute to the rise in the cost of EIA. In Pakistan EIA system, the owner of the unit is asked to pay a certain amount of review fee to concerned decision making agency. The cost in the EIA system shows the Environmental Currency, the value added to the natural environment. In the CS1 project about $1000 \mathrm{MT} /$ day of waste was proposed to be processed which shows augmentation in the valuation of environmental currency while in CS2 project the environmental cost was acceptable to proponent and sustainable use of natural resources was acknowledged. Similarly CS3, the Matiltan hydro power project installation capacity was $84 \mathrm{MW}$ and the socioeconomic condition of the locals will improve. The EIA system in Pakistan and KP Province fulfills this criterion of Christopher's Wood model.

\subsection{Strategic environmental assessment}

Strategic Environmental Assessment (SEA) is an assessment of "policies, plans and programs" which will provide the framework for each project. (Proactive EIA) or in other words, SEA is an efficient activity to assess the probable impacts of policies, plans or programs and thus assures their insertion in the process of decision making as well as socioeconomic concerns [[11]] or it is concluded that an investigative and consultative advancement with the objectives to incorporate the environmental concerns into the plans and policies as well as socioeconomic considerations[[12]].The National Impact Assessment Program of the International Union for Conservation of Nature \& Natural Resources (IUCN) is active in introducing the SEA into the EIA system of Pakistan leading to sustainable development. In Pakistan, after $18^{\text {th }}$ constitutional amendments the EPA KP, has placed SEA as section 12 in KPEPA 2014 but it has not been brought in actual practice due to new subject for actors. According to World Bank the environmental issues must be incorporated in the overall economic policies and thus SEA is receiving the worldwide attention [[13]]. This criterion now partially meets by the EIA system of Pakistan and KP.

The evaluation is summarized in the table given below:

Table 1: Evaluation of EIA System in Khyber Pakhtunkhwa (Pakistan) Using Christopher Wood Model

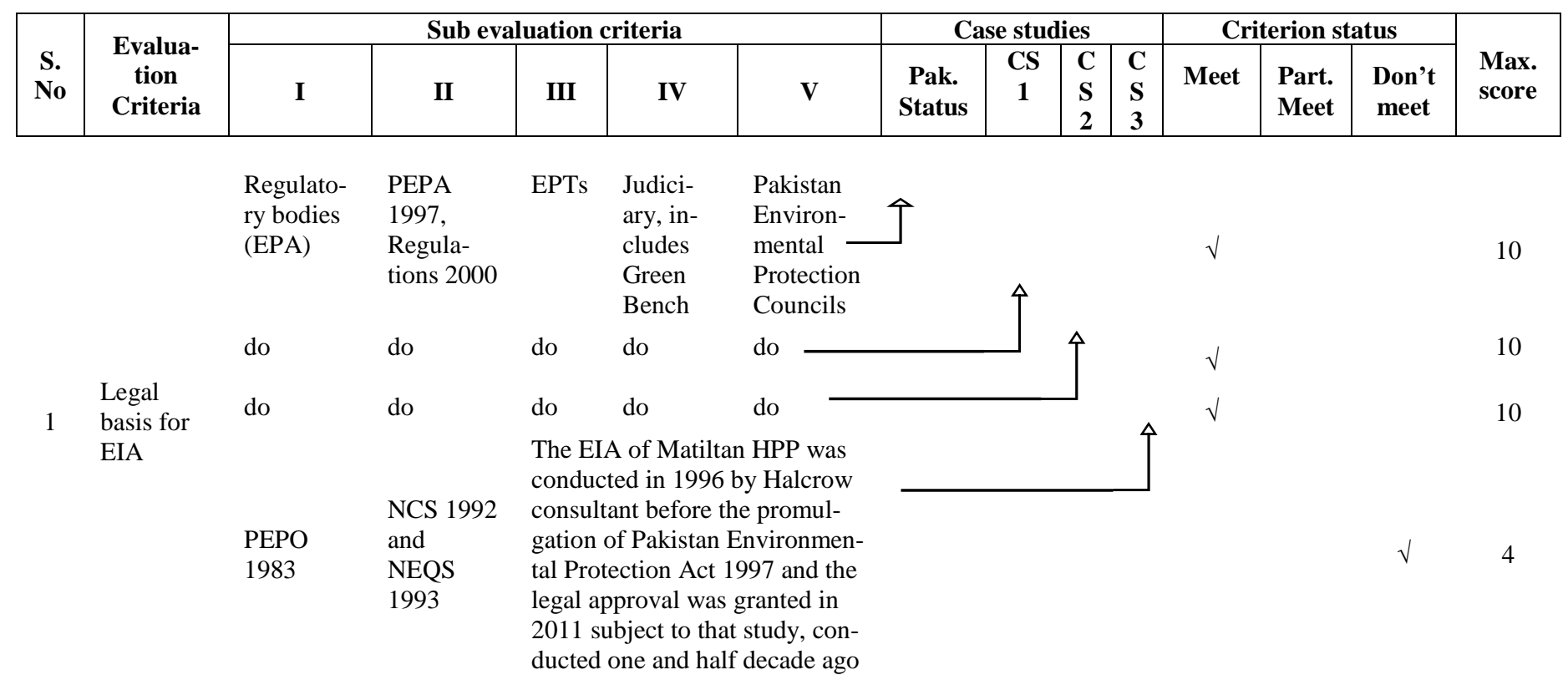




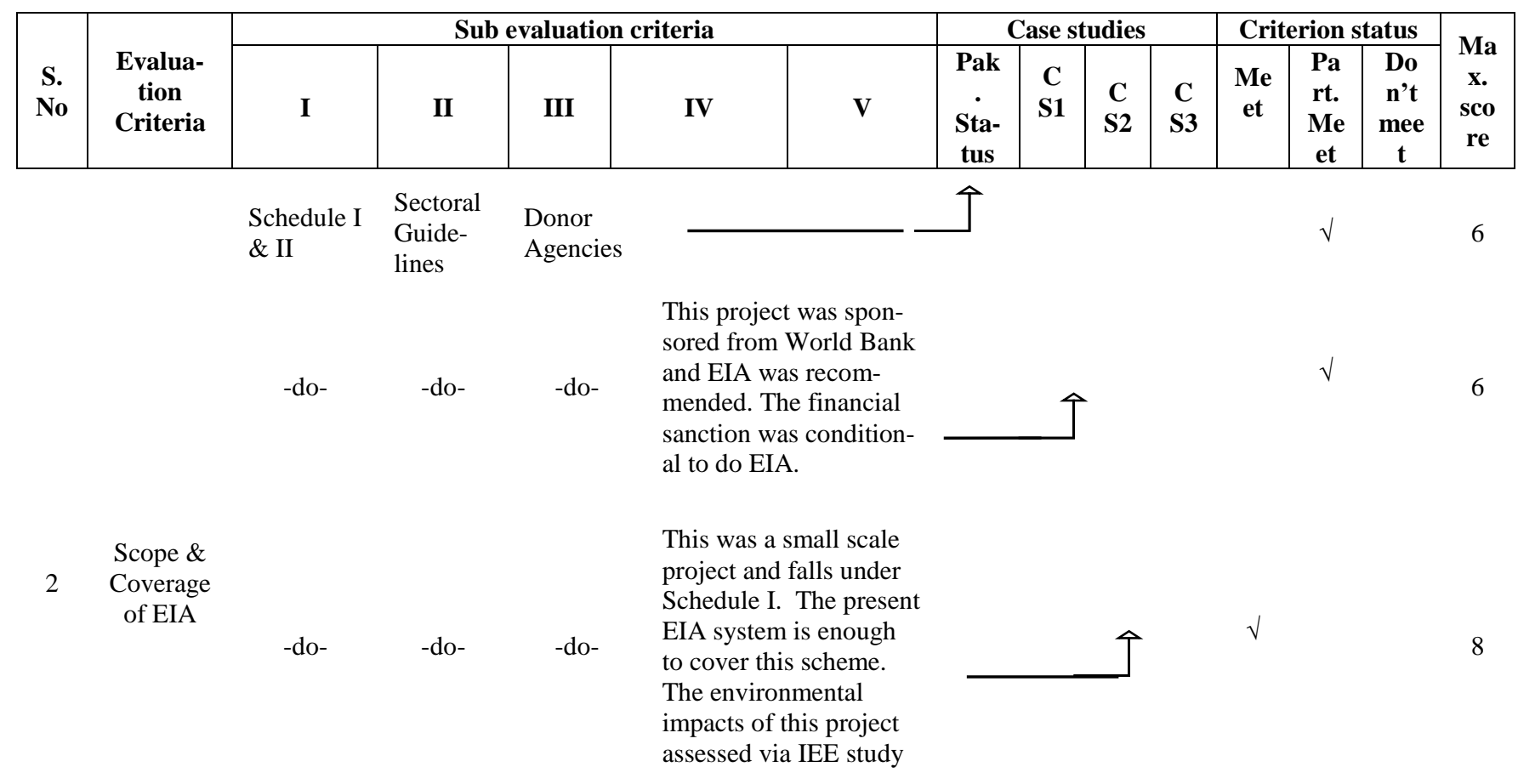

EPA Donor

Agency It was felt essential that the subject scheme needs the submission of EIA. So foreign consultant were

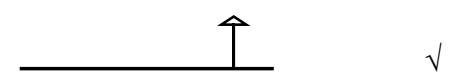
hired for assessment process.

\begin{tabular}{|c|c|c|c|c|}
\hline $\begin{array}{l}\text { Activity } \\
\text { alterna- } \\
\text { tives }\end{array}$ & $\begin{array}{l}\text { Location } \\
\text { alterna- } \\
\text { tives }\end{array}$ & $\begin{array}{l}\text { Demand } \\
\text { alterna- } \\
\text { tives }\end{array}$ & $\begin{array}{l}\text { Process } \\
\text { alterna- } \\
\text { tives }\end{array}$ & $\begin{array}{l}\text { Input al- } \\
\text { ternatives }\end{array}$ \\
\hline
\end{tabular}

Alternatives with respect to Activity, Location, Demand,

Process or Input has not been given in the whole project. The

EIA alter- location and process of the project was final due to Provincial natives government interest

No alternative option was sorted in this project.

Matiltan hydropower project has been sorted as an alternative source of power itself to other power generating projects like thermal or coal power generation and necessary alternative options with respect to location or process were not provicted

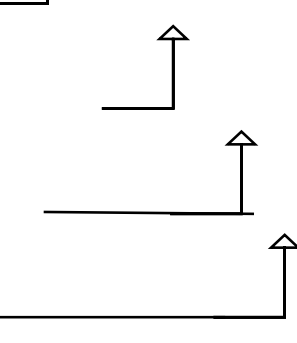

$\begin{array}{llll}\text { EPAs } & \begin{array}{l}\text { Schedule } \\ \text { I\&II }\end{array} & \begin{array}{l}\text { Section } \\ 12 \text { of } \\ \text { PEPA 97 }\end{array} & \begin{array}{l}\text { Donor } \\ \text { funded } \\ \text { Projects }\end{array} \\ & & \text { Section } & \begin{array}{l}\text { Donor } \\ \text { EPAs }\end{array} \\ & \text { Schedule } & \text { 12 of } & \text { funded } \\ & \text { I\&II } & \text { PEPA 97 } & \text { Projects }\end{array}$

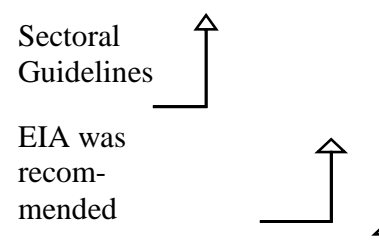

Screening

-do- $\quad$-do-

Pak EPA PEPO

IEE was recommended

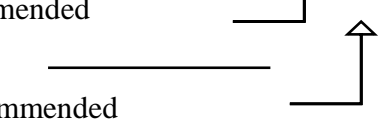

under

1983

funded

EIA was recommended

and conducted even

Environ-

Project

before the enactment of

Pakistan Environmental

Protection Act 1997

Urban

Affairs

which is appreciable.

Division

\begin{tabular}{|c|c|c|c|c|c|c|c|c|c|c|c|c|c|c|}
\hline \multirow[b]{2}{*}{$\begin{array}{l}\text { S. } \\
\text { No }\end{array}$} & \multirow[b]{2}{*}{$\begin{array}{l}\text { Evalua- } \\
\text { tion } \\
\text { Criteria }\end{array}$} & \multicolumn{5}{|c|}{ Sub evaluation criteria } & \multicolumn{4}{|c|}{ Case studies } & \multicolumn{3}{|c|}{ Criterion status } & \multirow{2}{*}{$\begin{array}{c}\text { Ma } \\
\text { x. } \\
\text { sco } \\
\text { re }\end{array}$} \\
\hline & & $\mathbf{I}$ & II & III & IV & $\mathbf{V}$ & $\begin{array}{l}\text { Pak } \\
\text { Sta- } \\
\text { tus }\end{array}$ & $\begin{array}{c}\text { C } \\
\text { S1 }\end{array}$ & $\begin{array}{c}\text { C } \\
\text { S2 }\end{array}$ & $\begin{array}{c}\text { C } \\
\text { S3 }\end{array}$ & $\begin{array}{c}\text { Me } \\
\text { et }\end{array}$ & $\begin{array}{c}\text { Pa } \\
\text { rt. } \\
\text { Me } \\
\text { et }\end{array}$ & $\begin{array}{c}\text { Do } \\
\text { n't } \\
\text { mee } \\
\text { t }\end{array}$ & \\
\hline 5 & $\begin{array}{l}\text { Scoping } \\
\text { of impacts }\end{array}$ & EPAs & IEE & EIA & SEA & $\begin{array}{l}\text { Sectoral } \\
\text { Guidelines }\end{array}$ & 个 & & & & $\sqrt{ }$ & & & 10 \\
\hline
\end{tabular}


In the scoping procedure it was judged that IEE would not be enough for the composting plant and needs detail study where environmental -dorisks are further minimized in doing EIA.

In the scoping procedure it was judged that IEE study would be

-do- $\quad$-do- $\quad$ enough for the proposed project where environmental risks are min-

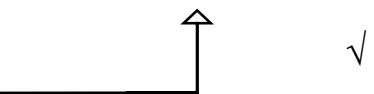

Federal imized

EPA

\section{EIA as a IEE}

condi- It was
tion by also an WB assessment option but inad-

As per possible expected impacts of the project the process of scoping was up to the equate. standards and the EIA

Guide-

lines for prepara-

EPAs

Donor tion \&

Prepara-

EIA report

$\begin{array}{ll}\text { Agen- } & \text { review of } \\ \text { cies } & \text { IEE/ } \\ & \text { EIA }\end{array}$

\section{Mandato-} ry under the environmental law

\section{Registered}

consultants

The assessment reports are EPA assets only. These are neither available on official Website nor any library in Khyber Pakhtunkhwa Review process is weak

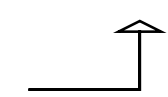
due to its unrewarding -do- $\quad$-do- $\quad$-do- $\quad$ nature and least experts are involved in the process of review.

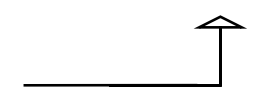

\section{review}

-do-

- do-

- do-

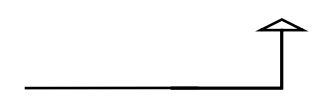

6

\begin{tabular}{|c|c|c|c|c|c|c|c|c|c|c|c|c|c|c|}
\hline \multirow[b]{2}{*}{$\begin{array}{c}\text { S. } \\
\text { No }\end{array}$} & \multirow[b]{2}{*}{$\begin{array}{l}\text { Evalua- } \\
\text { tion } \\
\text { Criteria }\end{array}$} & \multicolumn{5}{|c|}{ Sub evaluation criteria } & \multicolumn{4}{|c|}{ Case studies } & \multicolumn{3}{|c|}{ Criterion status } & \multirow[b]{2}{*}{$\begin{array}{c}\text { Ma } \\
\text { x. } \\
\text { sco } \\
\text { re }\end{array}$} \\
\hline & & I & II & III & IV & $\mathbf{V}$ & $\begin{array}{c}\text { Pak } \\
\text { Sta- } \\
\text { tus }\end{array}$ & $\begin{array}{c}\text { C } \\
\text { S1 }\end{array}$ & $\begin{array}{c}\text { C } \\
\text { S2 }\end{array}$ & $\begin{array}{c}\text { C } \\
\text { S3 }\end{array}$ & $\begin{array}{c}\text { Me } \\
\text { et }\end{array}$ & $\begin{array}{c}\text { Pa } \\
\text { rt. } \\
\text { Me } \\
\text { et }\end{array}$ & $\begin{array}{c}\text { Do } \\
\text { n't } \\
\text { mee } \\
\text { t }\end{array}$ & \\
\hline
\end{tabular}

Dictatorial approach: In this case decision is being made by a leading

Decision Adminis- Political- decision maker

8 making trative ly ori- Professional approach: In this type process approval ented of decision the professional judg-

approval ment \& logical justification is given

Consultative approach: In such dec1-

sion the target communities and 


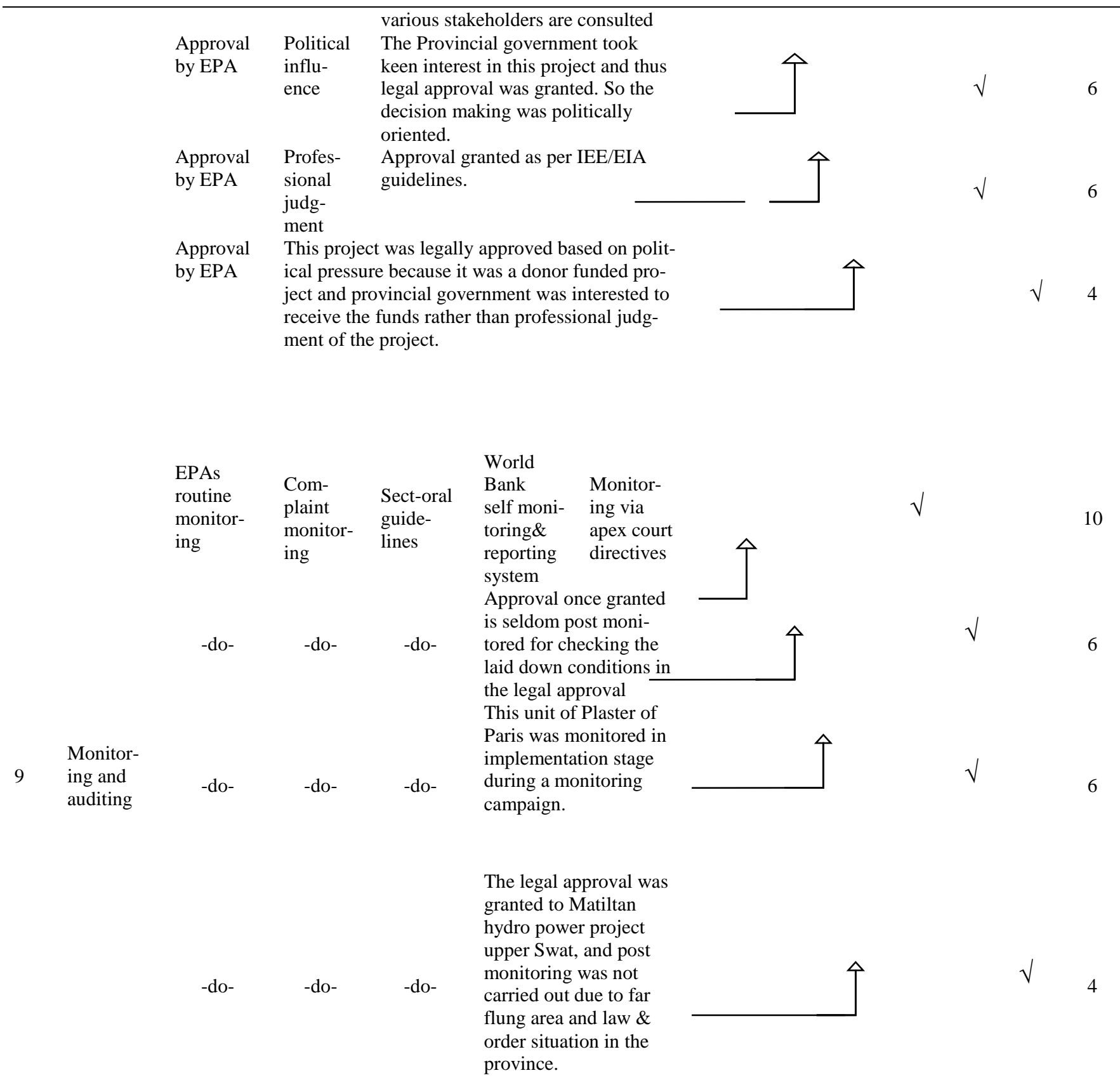

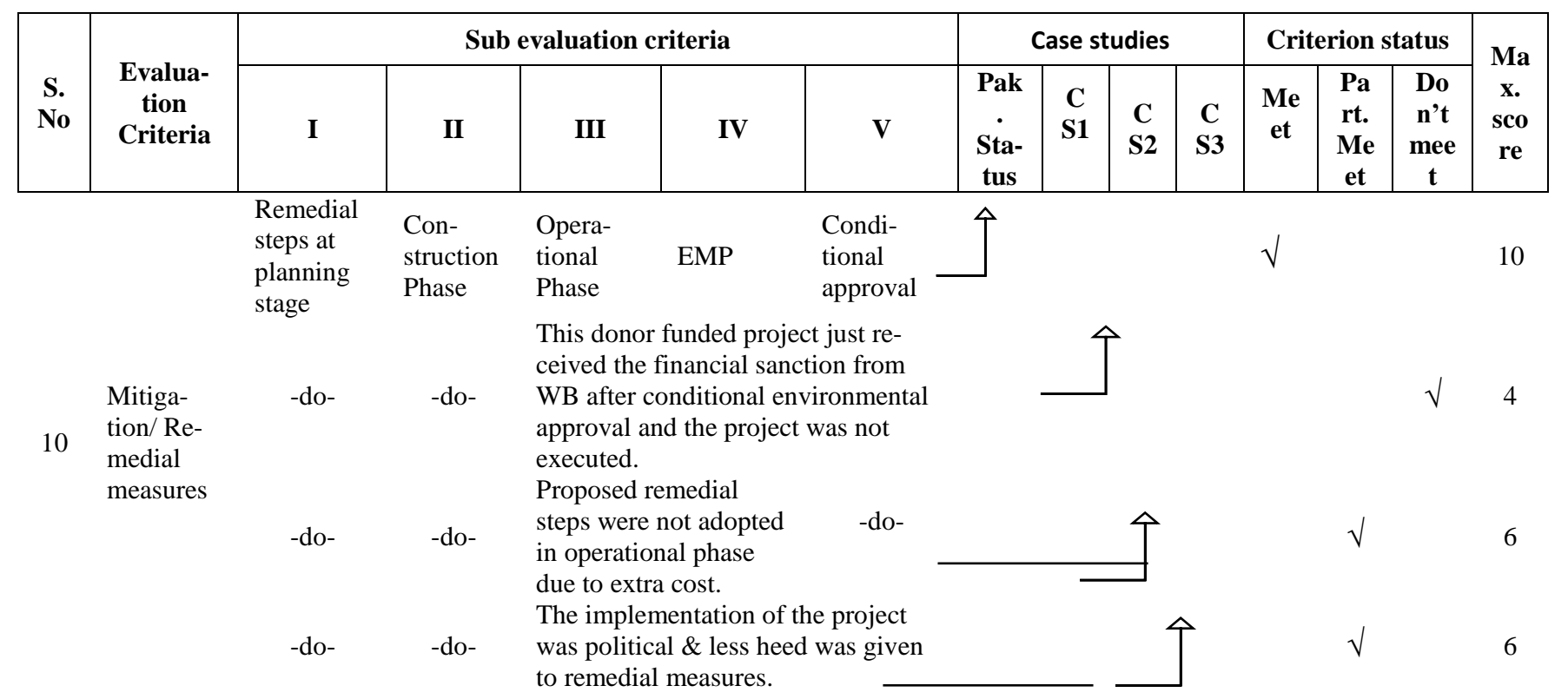


participa-

11 tion and

consulta-

tion.

$\begin{array}{lll}\text {-do- } & - \text { do- } & - \text { do- } \\ - \text { do- } & - \text { do- } & - \text { do- }\end{array}$

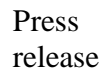

Condi-

tional

approval

Post

\& EMP

monitor-

ing Pro-

gramme

-do- $\quad-$ do-

EIA sys-

tem

Monitor-

ing

\section{NEQS}

compli-

ance -domented.

-do- $\quad$-do-

-do-do-
Letters

inviting

public

comments

In case of IEE study the project is exempt from the public hearing although EPA officials make sure field visit.

-do-

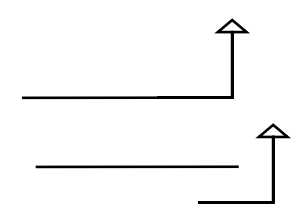

The monitoring may include sample collection and its need base analysis which is not carried out regularly.

Some time the EPA receives directives from the apex court to do moni-

toring and furnish the details accordingly. This project was not imple-

Monitoring is a continuous check process and although it doesn't work due to numerous constraints. This project was post monitored in a monitoring campaign.

There is no constructed environmental monitoring plan for environmental compliance, monitoring and reporting. This project was not post monitored due to law \& order situa-

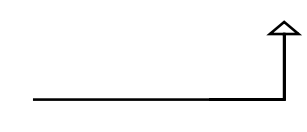
tion in Swat.

\begin{tabular}{|c|c|c|c|}
\hline $\begin{array}{l}\text { S. } \\
\text { No }\end{array}$ & $\begin{array}{l}\text { Evalua- } \\
\text { tion } \\
\text { Criteria }\end{array}$ & I & II \\
\hline & & $\begin{array}{l}\text { Review } \\
\text { fee }\end{array}$ & $\begin{array}{l}\text { Donor } \\
\text { funded } \\
\text { project }\end{array}$ \\
\hline 13 & $\begin{array}{l}\text { Costs } \\
\text { benefit } \\
\text { analysis } \\
\text { of EIA } \\
\text { system. }\end{array}$ & -do- & -do- \\
\hline
\end{tabular}

-do-do-

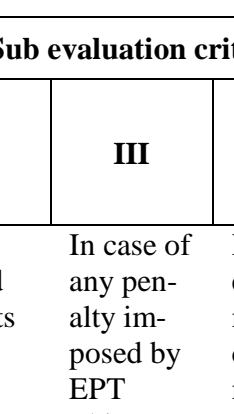

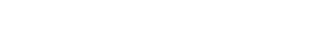

This was an effective plan and waste waste of the whole Peshawar district were supposed to be collected and about $1000 \mathrm{MT} /$ day solid waste to be processed and the byproduct in form of fertilizer would be generated. This fertilizer would be cheaper and nutrient rich comparatively.

Sustaina- Due to the presence of IEE/EIA

ble use of system the project was made natural environmentally sound and the resources proponent acknowledged that locals of the area will be given preference as skilled and un-

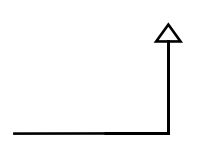

$\sqrt{ }$ 8 


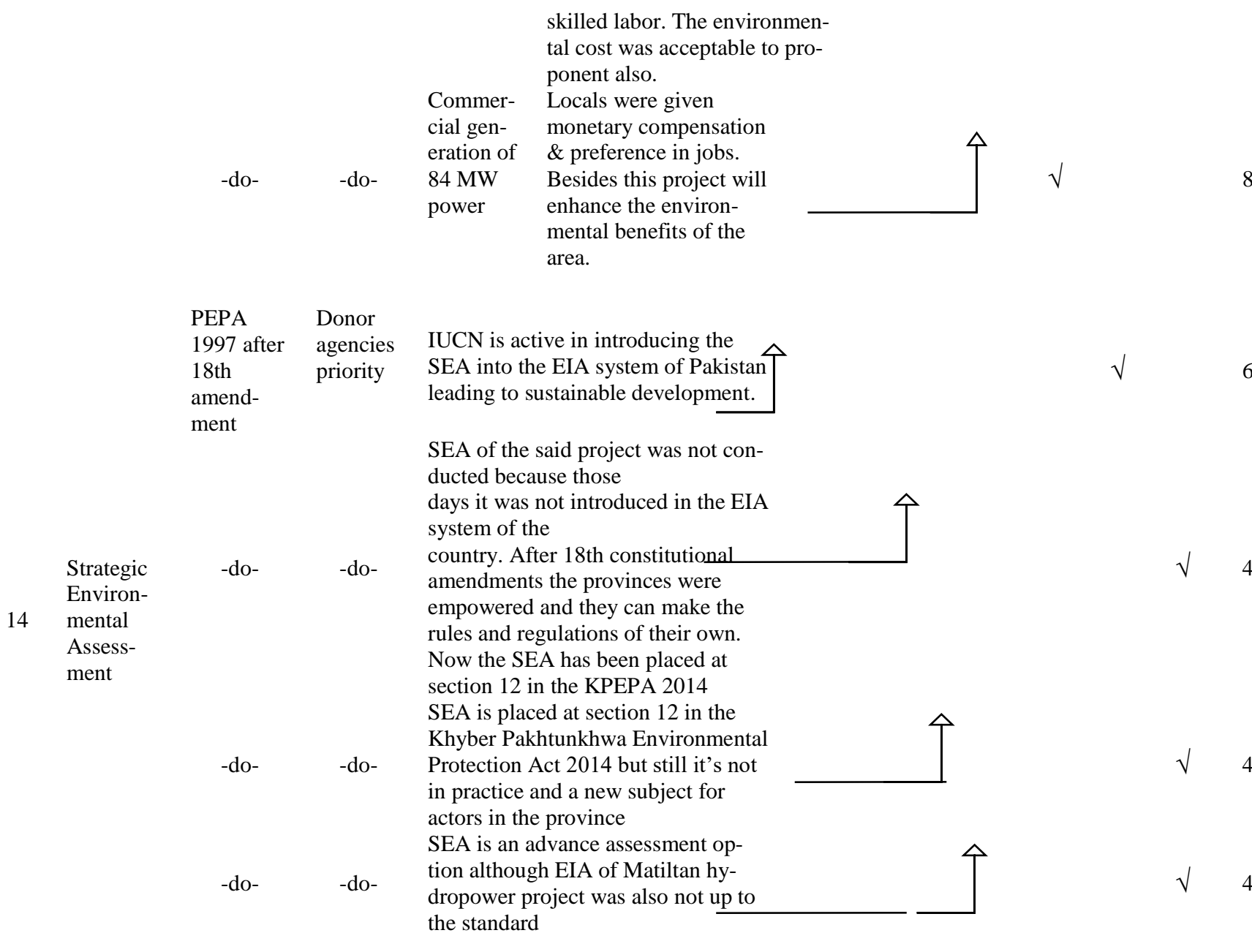

\section{Conclusion}

Based on the findings derived from the application of Christopher Wood Model to the EIA process in Pakistan, it is concluded that the EIA system in the country especially in the province of KP is not proficient enough in way of alternative options in EIA, decision making, monitoring process including the post-monitoring and environmental compliance, and Strategic Environmental Assessment at the implementation level. Besides, the EIA system doesn't have any legal provision for the authorization of a consultant although they are kept involved in the whole EIA process. Most of the mega projects which may receive the financial sanctions from the donor agencies, seldom implement the EIA in actual practice. Some of the terms provided in the Pakistan Environmental Protection Act 1997 are dubious and need further explanation for instance the environmental laboratories, environmental magistrate and urban projects. There is a need of a wellconstructed environmental monitoring plan which might cover the numerous environmental areas and may compel the monitoring team for reporting. The implementation of the Strategic Environmental Assessment is significant in order to cope with the environmental stress. There is a need to consider EIA in decision making and make it free from political influence. Moreover, the alternative options should also be exercised, promote environmental education, recommendation of research based remedial measures and conduct regular training and awareness in the field of EIA. This will help in further strengthening and stabilization of the EIA system in the KP Province.

\section{References}

[1] Ortolano, L., Jenkins, B. and Abracosa, R. (1987). Speculations on when and why EIA is effective. Environmental Impact Assessment Review, 7(4), pp.285-292.https://doi.org/10.1016/01959255(87)90002-3.

[2] Hirji, R. and Ortolano, L. (1991). EIA effectiveness and mechanisms of control. International Journal of Water Resources Development, 7(3), pp.154167.https://doi.org/10.1080/07900629108722508.

[3] Wen-Shyan, L., Williams, W. P. and A.W. Bark, 1996. Development of an Environmental Impact Assessment Evaluation Model and Its Application: Taiwan Case Study. Environmental Impact Assessment Review, 16 (2): 115-133.https://doi.org/10.1016/01959255(95)00107-7.

[4] Wood, C. and Coppell, L. (1999) 'An evaluation of the Hong Kong environmental impact assessment system', Impact Assessment and Project Appraisal, 17(1), pp. 2131.https://doi.org/10.3152/147154699781767936.

[5] Baker, A; and C, Wood; (2002). A comparative evaluation of the EIA systems in Egypt, Turkey and Tunisia. Environmental Impact Assessment Review, 22(3), pp.213234.https://doi.org/10.1016/S0195-9255(02)00004-5.

[6] Balsam, A, and C, Wood (2002). A comparative Evaluation of the EIA systems in Egypt, Turkey and Tunisia. Environmental Impact Assessment Review 19 (4) 387-404.

[7] Riffat, R. and Khan, D., (2006). A review and evaluation of the environmental impact assessment process in Pakistan, Journal of Applied sciences and environmental sanitation, 1, 17-29.

[8] Murthy, A. and Patra, H.S. (2005) Environment impact assessment process in India and the drawbacks, Environment Conservation Team Report. Available at: https://elibrarywcl.files.wordpress.com/2015/02/environment- 
impact-assessment-process-in-india-and-the-drawbacks-1.pdf (Accessed: 16 November 2012).

[9] Government of Pakistan (GoP). (1983). Pakistan Environmental Protection Ordinance, 1983, Islamabad; Gazette of Pakistan

[10] Government of Pakistan (GoP). (1997). Pakistan Environmental Protection Act, 1997, Gazette of Pakistan

[11] Sadler B. \&Verheem R. (1996). Strategic Environmental Assessment: Status, Challenges and Future Directions. Ministry of Housing, Spatial Planning and the Environment, the Netherlands, and the International Study of Effectiveness of Environmental Assessment.

[12] OECD. 2006. The challenge of capacity development - working towards good practice. DAC Guidelines and Reference Series. Paris, France: OECD. Retrieved 27 March 2016 from: www.oecd.org/dataoecd/4/36/36326495.pdf.

[13] World Bank, 1996. The Impact of Environmental Assessment: The World Bank's Experience, Second Environmental Assessment Review. Land, Water, and Natural Habitats Division, Environmental Department, the World Bank, Washington, D.C.

[14] Alshuwaikhat, H. (2005). Strategic environmental assessment can help solve environmental impact assessment failures in developing countries. Environmental Impact Assessment Review, 25(4), pp.307-317.https://doi.org/10.1016/j.eiar.2004.09.003.

[15] Annandale, D. (2001). Developing and evaluating environmental impact assessment systems for small developing countries. Impact Assessment and Project Appraisal, 19(3), pp.187193.https://doi.org/10.3152/147154601781766998.

[16] Aslam, F. (2006). Environmental Impact Assessment in PakistanOverview, Implementation and Effectiveness. Master. Department of Architecture and Built Environment. KTH University. Sweden.

[17] Government of Pakistan (GoP). (2002). Pakistan Environmenta Protection Agency Country Assessment Report. Revised Draft-2. Ministry of Environment, Local Government and Rural Development World Summit on Sustainable Development, Johannesburg, South Africa.

[18] Jennifer C. Li., (2008) Environmental Impact Assessments in Developing Countries: An Opportunity for Greater Environmental Security? Available at: http://fess-global.org/WorkingPapers/EIA.pdf (Accessed: 16 August 2012).

[19] Leu, W., Williams, W. and Bark, A. (1996). Development of an en vironmental impact assessment evaluation model and its application: Taiwan case study. Environmental Impact Assessment Review, 16(2), pp.115-133.https://doi.org/10.1016/0195-9255(95)00107-7.

[20] Modak, P. and Biswas, A., (1999). Conducting environmental impact assessment in developing countries Toronto: United Nations University Press.

[21] Nizami, A.-S., Molander, S., Asam, Z., Rafique, R., Korres, N.E., Kiely, G. and Murphy, J.D. (2011) 'Comparative analysis using EIA for developed and developing countries: Case studies of hydroelectric power plants in Pakistan, Norway and Sweden', International Journal of Sustainable Development \& World Ecology, 18(2), pp. 134142.https://doi.org/10.1080/13504509.2011.559399.

[22] Ogola,A.,Pacifica,F.(2007) Environmental Impact Assessment general procedures, Geothermal Training Program in Kenya.

[23] Ortolano, L. and Shepherd, A. (1995). Environmental Impact Assessment: Challenges and Opportunities. Impact Assessment, 13(1), pp.3-30.https://doi.org/10.1080/07349165.1995.9726076.

[24] Wood, C. (1993). Environmental Impact Assessment in Victoria: Australian Discretion Rules EA!.Journal of Environmental Management, 39(4), pp.281295.https://doi.org/10.1006/jema.1993.1071.

[25] Wood, C. (2003) Environmental Impact Assessment in Developing Countries: An Overview. Conference On, New Directions in Impact Assessment for Development: Methods and Practice. 